\title{
PEREMPUAN DALAM NOVEL DAKWAH: KAJIAN KARYA ASMA NADIA DALAM PERSPEKTIF HALL
}

Women in Da'wah Novel: The Study of Asma Nadia's Works in Hall's Perspective

\author{
Maycherlita Supandi \\ Fakultas Adab Dan Humaniora, Universitas Islam Negeri Sunan Ampel Surabaya \\ Jl. A. Yani Nomor 117 Surabaya \\ Email: magical27may@gmail.com
}

\begin{abstract}
Abstrak: Artikel ini berfokus pada bagaimana karakter-karakter perempuan ditampilkan di dalam novel dakwah karya Asma Nadia untuk mengkaji eksistensi pengarang dan karyanya dalam ranah kultural dan agama. Fokus artikel ini adalah 1) bagaimana tokoh perempuan direpresentasikan di dalam novel Assalamualaikum Beijing dan Surga Yang Tak Dirindukan, 2) apa makna yang ditandai dengan posisi tokoh perempuan di dalam novel Assalamualaikum Beijing dan Surga Yang Tak Dirindukan. Artikel ini menggunakan teori representasi Stuart Hall dan menunjukkan bahwa terlepas dari semangat kesetaraan gender yang digemakan Forum Lingkar Pena, perempuan masih direpresentasikan dengan karakterkarakter nilai patriarki dan itu berarti makna nilai liberation dan equality yang dipegang oleh Asma Nadia masih berlandaskan tafsir klasik atas teks-teks suci agama Islam. Dengan begitu, nilai persamaan yang dimaksudkan menjadi semangat karya-karyanya, tidak tercermin dalam ranah mikro di dalam Narasi yang dibangun Asma Nadia.
\end{abstract}

Kata-kata Kunci: Asma Nadia, Novel Dakwah, Forum Lingkar Pena, Stuart Hall, Representasi

Abstract: This article focuses on how female characters are featured in Asma Nadia's da'wah novels to study the existence of author and her works in the cultural and religious realm. The focus of this article is 1) how the female character is represented in the novel Assalamualaikum of Beijing and the Surga Yang Tak Dirindukan, 2) what is the significance marked by the position of female characters in the novel Assalamualaikum Beijing and Surga Yang Tak Dirindukan. This article uses Stuart Hall's theory of representation and shows that apart from the spirit of gender equality echoed by the Pen Circle Forum, women are still represented by patriarchal characters and that means the value of liberation and equality held by Asma Nadia is still based on the classical interpretation of Islamic sacred texts. That 
way, the value of the equation which is meant to be the spirit of the Asma Nadia's works, is not reflected in the micro-realm within the Narration built by Asma Nadia.

Keywords: Asma Nadia, Da'wah Novels, Forum Lingkar Pena, Stuart Hall, Representation

\section{Pengantar}

Novel dakwah atau yang sering disebut dengan sastra islam mulai mendapat momentum-nya setelah Ayat-Ayat Cinta, film yang diadaptasi dari novel berjudul sama karya Habibburrahman el-Shirazy, meraih kesuksesan pada tahun 2005 silam. Setelahnya, karya-karya serupa yang menawarkan nilai-nilai islam pada jalinan narasinya, baik berupa karya sastra maupun produk budaya lain seperti sinema televisi, mulai muncul ke permukaan. Implikasi yang ditimbulkan kepada penikmat produk budaya tersebut juga mengindikasikan bahwa satra dakwah tidak hanya mendapatkan momentum-nya, namun juga berhasil dalam konteks pertarungan ideologis dan menggantikan genre feminis yang terkenal dengan Sastra Wangi pada era sebelumnya. Bahkan, Arnez (Arnez, 2009) menyebutnya dengan istilah 'antitesis dari Sastra Wangi' untuk mempertegas perbedaan kedua genre tersebut dan menekankan peralihan yang terjadi. Contoh praktis dari argumen di atas sekaligus bukti dari implikasi masif atas genre sastra dakwah kepada masyarakat adalah munculnya produk budaya seperti sinema televisi berjudul Munajat Cinta pada tahun 2008 silam dengan tema besar poligami, serupa dengan tema besar yang diangkat novel dan film Ayat-Ayat Cinta, dengan salah satu pemeran utama yang juga merupakan pemain utama pada film tersebut. Hal tersebut belum termasuk munculnya karya-karya sastra dengan genre islam dan dakwah seperti Dzikir Jantung Fatimah karya Naning Pranoto, Ramadhan Terakhir Ludwig karya Mahabb Adib-Abdillah, dan Kitab Cinta Yusuf Zulaikha karya Taufiqurrahman al-Azizy.

Kesuksesan genre 'baru' tersebut dilihat sebagai peralihan selera pasar dari genre feminisme dengan karakteristik kebebasan perempuan atas tubuhnya sehingga muncul anggapan bahwa karyakarya di bawah naungan Sastra Wangi terlalu vulgar dalam penggambarannya terhadap perempuan. Hal tersebut juga menandai kesuksesan genre islami tersebut dalam misinya menyebarkan ajaran moral dan nilai-nilai islam (Azwar, 2012), hal yang dianggap bertentangan dengan genre Sastra Wangi. Dengan penjabaran tersebut, berbicara tentang novel dakwah, nama Asma Nadia merupakan nama yang signifikan. 
Asma Nadia merupakan salah satu figur prominent dalam Forum Lingkar Pena, organisasi kepenulisan dakwah dan Islam yang mayoritas anggotanya merupakan perempuan, baik mahasiswa maupun non-mahasiswa (Arnez, Dimensions of Morality: The Transnational Writers' Collective Forum Lingkar Pena, 2016). Dengan begitu, Asma Nadia dan karya-karyanya dapat dianggap sebagai figur yang secara simbolis mewakili keterlibatan perempuan dalam hal non-domestik. Terlebih lagi, islam sendiri oleh beberapa pihak dinilai sangat patriarkal dan cenderung mendomestifikasi perempuan. Secara historis, klaim tersebut didukung dengan beberapa bukti otentik terkait domestifikasi perempuan. Islam menyiratkan bahwa laki-laki adalah makhluk unggul dibandingkan perempuan. el Saadawi (El Saadawi, 2001) menjelaskan bahwa,

...keunggulan laki-laki atas
perempuan adalah alasan di
belakang fakta bahwa para nabi
selalu menggunakan kata laki-laki
ketika menunjuk kepada Allah dan
berbicara tentangNya. Semua nabi
adalah laki-laki dan tidak pernah ada
nabi perempuan. Orang pertama di
bumi adalah Adam yang
ditempatkan di atas Hawa karena ia
adalah asal-usul ras manusia, lebih
kuat dan memberi kehidupan pada
Hawa dari salah satu tulang
rusuknya...

Dengan begitu, eksistensi Asma Nadia beserta karya-karyanya yang hingga kini semakin kokoh dalam kancah kultural merupakan sebuah indikator akan kesuksesan lain, selain kesuksesan dalam melanggengkan ideologi islam ditengah kontestasi ideologi dengan Sastra Wangi, yaitu kesuksesan dalam merangkul pihak terdomestifikasi untuk menjejak pada ranah publik. Dalam esainya, Arnez dan Dewojati (Arnez \& Dewojati, Sexuality, Morality and The Female Role : Observation On Recent Indonesian's Women's Literature, 2010) mendukung klaim tersebut dengan berargumen bahwa perempuan Indonesia 'telah menjadi subyek dari redefinisi' yang berarti bahwa posisi, identitas dan label yang melekat pada perempuan kini mulai dipertanyakan dan mulai menuju pada perubahan. Lebih jauh, Arnez juga menjelaskan fenomena tersebut dengan memaparkan tentang Organisasi Massa Islam di Indonesia yang memiliki cabang keperempuanan merupakan bentuk kekuatan baru yang disebut feminisme islam yang bertindak sebagai agen sosial yang membawa perubahan pada hal-hal keperempuanan (Arnez, Empowering Women Through islam: Fatayat NU Between Tradition And Change, 2010). Fenomena tersebut tercermin di dalam beberapa karya Asma Nadia. 
Fenomena tersebut merupakan klaim yang krusial dalam menandai posisi karya Asma Nadia dalam kancah kultural. Akan tetapi, semangat pembaharuan yang diusung oleh pengarang juga menjadi subyek dari kritik yang mempertanyakan kembali validitas klaim tersebut. Hal tersebut didasari oleh fakta bahwa nilai patriarki telah mendarah daging khususnya dalam konteks Indonesia kontemporer. Jika klaim di atas adalah benar bahwa Forum Lingkar Pena, khususnya Asma Nadia dan karya-karyanya telah membawa definisi baru pada perempuan dan berujung pada kesetaraan antara perempuan dan laki-laki, maka hal tersebut akan tercermin di dalam karya-karyanya.

Artikel ini akan mengulas dua karya signifikan Asma Nadia terutama dalam kaitannya dengan posisi hierarkis perempuan di dalam narasi. Hal ini untuk memvalidasi apakah pengaruh pembaharuan definisi dan kesetaraan perempuan yang diusung Forum Lingkar Pena telah mengakar pada skala mikro para anggota perempuannya dan tercermin di dalam karakter novel, ataukah hanya sebatas pemberdayaan para anggota tanpa adanya nilai kesetaraan gender yang ditanamkan. Artikel ini akan membahas dua karya terkenal Asma Nadia yang berjudul Assalamualaikum Beijing dan Surga Yang Tak Dirindukan. Kedua karya tersebut dipilih berdasarkan pertimbangan bahwa keduanya mendapatkan banyak publisitas hingga proses keranisasi. Oleh karena itu, artikel ini bergerak sesuai kerangka analisa teori representasi oleh Stuart Hall untuk melihat bagaimana perempuan direpresentasikan dan mengindikasikan posisi hierarkisnya di dalam narasi. Dengan begitu, artikel ini akan membahas dua hal yaitu bagaimana tokoh perempuan direpresentasikan di dalam novel Assalamualaikum Beijing dan Surga Yang Tak Dirindukan dan apa makna yang ditandai dengan posisi tokoh perempuan di dalam kedua novel tersebut.

\section{Landasan Teori: Stuart Hall's}

\section{Representation}

Representasi dalam perspektif Stuart Hall didefinisikan sebagai proses menciptaan suatu makna yang menggunakan medium bahasa sebagai elemen pembentuk makna yang hendak disampaikan. Hal ini erat kaitannya dengan ideologi pemberi makna sehingga hubungan antara analisa wacana yang erat hubungannya dengan kajian ideologi dengan representasi menjadi saling berkaitan erat. Dengan kata lain, makna yang diterima sebagai implikasi dari perepresentasian suatu hal tertentu hadir disebabkan oleh adanya ideologi pihak pemberi makna yang bermain-main dalam obyek yang direpresentasikan melalui bahasa tertentu. 
Dua hal yang menjadi fokus utama dalam kajian terkait representasi dalam perspektif Stuart Hall yaitu pihak representatif (representative) dan pihak yang terepresentasikan (represented) (Hall, 1997). Struktur bahasa yang menjadi medium penyampaian reprsentasi menunjukkan adanya atribut aktif dan pasif dalam kedua fokus utama di atas. Dengan begitu, pihak representatif memiliki kuasa untuk menampilkan pihak terepresentasikan sesuai yang dikehendaki yang tentu saja ada campur tangan ideologi.

\section{Metode Penelitian}

Penelitian ini menggunakan pendekatan kualitatif dengan metode analisis konten narasi pada novel. Analisa narasi dilakukan pada novel karya Asma Nadia yang berjudul Assalamualaikum Beijing dan Surga Yang Tak Drindukan. Alur analisa dilakukan dengan perspektif Teori Representasi Stuart Hall yang terdiri dari metode pengumpulan data dan metode analisa data.

Metode pengumpulan data dilakukan dengan mengkaji narasi novel dan melakukan klasifikasi narasi sesuai kategori yang diinginkan yaitu bagaimana perempua ditampilkan. Data yang dikumpulkan berupa narasi deskriptif dan dialog.
Metode analisa data dilakukan dengan mengkaji data yang terkumpul untuk mengetahui representasi kedua gender. Analisa lalu berlanjut pada susunan hierarkis antara kedua gender yang muncul di dalam narasi.

\section{Hasil Pembahasan}

Mahayana menulis pada sebuah artikel yang berjudul Menulis Itu Ibadah yang termuat dalam majalah Horison juli 2015 bahwa karya sastra bisa dianggap sebagai refleksi evaluatif pengarang atas problem sosial yang terjadi di sekitarnya. Dengan kata lain, apa yang ada di luar pengarang dapat tercermin pada karya yang ia buat. Tidak hanya problem sosial, karya sastra juga dilihat sebagai analogi dari semesta pengarangnya, termasuk juga ideologi yang dianut.

\section{Posisi Dan Keberadaan Perempuan}

\section{Dalam Assalamualaikum Beijing dan}

\section{Surga Yang Tak Dirindukan}

Pada novel Assalamualaikum Beijing, representasi gender yang ada di dalam novel tersebut dapat dianalisa melalui penggambaran dua tokoh utama perempuan, yaitu tokoh Asmara dan Anita. Secara karakter, Nadia tidak menyiratkan adanya perempuan lemah dengan memberikan atribut kuat beserta masa lalu tokoh Asmara yang membentuknya menjadi tokoh dengan 
karakter sedemikian rupa. Asmara ditampilkan sebagai korban perceraian orang tuanya yang membuatnya memiliki karakter kuat. Hal tersebut adalah representasi yang biasa melekat pada tokoh utama dalam sebuah cerita.

Sementara itu, tokoh Anita adalah kebalikan dari tokoh Asmara. Tokoh tersebut dihadirkan sebagai perempuan kejawen yang pada akhirnya memberikannya karakter tertentu dan membentuk cara berpikirnya dalam meraih ambisinya yang hadir dalam tokoh Dewa. Tokoh Anita menggunakan kodrat perempuannya, yaitu tubuhnya untuk mendapatkan tokoh Dewa. Apa yang dilakukan tokoh Anita menunjukkan posisinya sebagai perempuan sekaligus sebagai obyek yang hanya mampu menggunakan daya tarik seksualnya untuk mendapatkan apa yang ia inginkan.

Ada beberapa perdebatan terkait penggunaan tubuh perempuan beserta kebebasan perempuan atas tubuhnya sendiri. Dalam istilah feminisme radikal, tubuh merupakan sebuah konsep yang harus dihargai kebebasannya. Hal tersebut mengindikasikan pemilik memiliki hak penuh terhadap tubuhnya sehingga pornografi dan aktifitas promiskuiti dianggap sebagai simbol kebebasan dan kesetaraan (Tong, 2010). Akan tetapi, berbeda dengan pemikiran tersebut, beberapa pihak ada yang menganggap aktifitas semacam itu sebagai bentuk opresi sebab perempuan hanya sebagai obyek dari laki-laki.

Dan, siluet yang terbentuk dari cara berpakaian Anita mengusik kelelakiannya. Kedua mata anak muda itu terpana. Anita tersenyum, semakin mendekat. (Hal. 36)

Tokoh Anita menggunakan tubuhnya untuk mendapatkan tokoh Dewa dan ia melakukan hal tersebut dengan mood keputusasaan sehingga tubuhnya adalah satu-satunya cara. Itu berarti tokoh Anita memposisikan dirinya (dan juga tubuhnya) sebagai obyek untuk kepuasan tokoh laki-laki. Dengan begitu, secara hierarkis tokoh tersebut berada pada posisi inferior.

Di dalam teks, posisi hierarkis perempuan yang inferior dapat dikaji melalui addressing words yang mengacu pada tokoh perempuan. Nadia merujuk pada tokoh perempuan dengan menggunakan rujukan kepemilikan, seperti 'gadis-nya', 'gadis mungilnya' dan 'Ashima-nya' ketika merujuk pada tokoh Asmara.

Gadis mungilnya suka melibatkan Dewa, hingga tak merasa seperti orang asing. (Hal. 105)

Pertanyaan gadisnya, menambah keresahan yang coba dikemas laki-laki itu dalam senyuman. (Hal. 2) 
Ashima-nya bisa saja dekat, tetapi tersembunyi di keramaian. (Hal. 71)

Akhiran 'nya' pada setiap kata reference yang digunakan pengarang seolah merujuk pada fakta bahwa tokoh Asmara merupakan 'milik' dari tokoh lakilaki, yaitu Dewa dan Zhongwen. Tentunya, karakter pasif melekat pada sesuatu yang menjadi hak milik sementara karakter aktif melekat pada sesuatu atau seseorang sebagai pemilik. Karakter tersebut bertentangan dengan penggambaran karakter Asmara yang digambarkan memiliki kemauan yang kuat khas novelnovel Asma Nadia yang lain dengan tokoh utama perempuan. Berbeda dengan penggunaan suffix kepemilikan untuk mengacu pada tokoh perempuan, Nadia tidak menggunakan hal yang sama untuk mengacu pada tokoh Dewa dan Zongwen.

Hal kepemilikan tersebut menjadi krusial dalam kajian terhadap posisi perempuan. Kepemilikan atau hak milik merupakan awal mula subordinasi dan obyektifikasi perempuan. Engels berpendapat bahwa subordinasi perempuan dimulai dengan terjadinya perkembangan milik pribadi dan semua itu berkembang secara historis (Bhasin, 1996). Penggunaan suffix tersebut, otomatis menegasi karakter kuat Asmara; sekuat apapun penggambaran karakter Asmara, pada dasarnya ia tetap menjadi 'milik' tokoh laki-laki dalam cerita tersebut yang menandai posisi hierarkisnya yang berada di bawah laki-laki.

Perbedaan yang cukup kontras juga tampak dalam penggambaran fisik tokohtokoh dengan penggunaan diksi tertentu. Diksi-diksi yang berasosiasi dengan karakter 'kuat' dan 'superior' diberikan kepada tokoh-tokoh laki-laki sementara hal sebaliknya digunakan untuk mendeskripsikan tokoh perempuan. Diksi seperti 'rahang tegas', 'mata cerdas', dan 'rahang kukuh' digunakan Nadia dalam penggambaran tokoh Zongwen. Sementara kata-kata seperti 'kelopak indah' dan 'gadis berwajah mungil' digunakan untuk penggambaran tokoh Asmara.

Asma menghembuskan nafas lega.
Akhirnya pertolongan Allah
datang juga lewat pemuda dengan
rahang tegas yang kontras dan
sepasang mata cerdas yang
bersinar lembut. (Hal. 10)

Gadis berwajah mungil di depannya mengangguk. (Hal. 5)

Diksi 'tegas', 'kukuh' dan 'cerdas' berasosiasi pada pihak pemilik power yang mana adalah pihak laki-laki di dalam karya tersebut. Sementara itu, diksi 'mungil' didefinisikan sebagai sesuatu yang berada dalam jangkauan dan sekaligus rapuh. Kata-kata 'tegas', 'cerdas' dan 'kukuh' menyerukan bahwa tokoh laki-laki adalah gender yang terlahir sebagai pihak superior. Bahkan, nama tokoh Zhongwen 
secara literal berarti 'yang terpelajar'. Hal tersebut semakin melebarkan perbedaan antara laki-laki dan perempuan di dalam karya tersebut.

Penggambaran tokoh yang memiliki kesamaan juga terjadi pada tokoh perempuan di karya Asma Nadia yang lain yaitu Surga Yang Tak Dirindukan. Dalam novel Surga Yang Tak Dirindukan, hal signifikan yang perlu diperhatikan adalah istilah poligami yang diusung pengarang sebagai tema besar. Sejarah mencatat poligami sebagai bentuk kekuasaan laki-laki atas perempuan. Namun, yang perlu diperhatikan adalah bagaimana laki-laki berlindung di balik istilah 'sunnah' untuk menjustifikasi perbuatannya tanpa adanya pemahaman menyeluruh terkait apa yang dilakukan Nabi Muhammad SAW (Muhammad, 2004). Konstruksi sosial yang mengandung nilai-nilai patriarki secara tidak langsung juga ikut menancapkan kekuatannya melalui institusi legal mikro seperti pernikahan. Di dalam narasi, tokoh Pras tidak memiliki justifikasi yang cukup obyektif untuk melakukan poligami, terlepas dari usaha Nadia memberikan legitimasi tersebut dengan menampilkan kondisi tokoh Mei Rose yang menyedihkan, sehingga menjadi oposisi tokoh Arini. Akan tetapi, poligami tetap terlaksana tanpa sepengetahuan tokoh
Arini. Dengan kata lain, laki-laki digambarkan aktif sedangkan perempuan digambarkan pasif.

Sekuen narasi terpanjang berfokus pada Tokoh Arini yang mengalami pergulatan batin setelah mengetahui suaminya, tokoh Pras, telah melakukan poligami. Sepanjang sekuen tersebut, konflik batin tokoh Arini memenuhi jalan narasi tanpa sikap aktif untuk bergerak menuju resolusi permasalahan dalam narasi. Satu-satunya aksi yang dilakukan tokoh tersebut sebelum narasi bergerak menuju akhir adalah dengan menuliskan kisah yang sama dalam karir kepenulisannya. Bahkan, pada titik tertentu, tokoh Arini dapat dianalogikan dengan tokoh rekaan ciptaan tokoh Arini di dalam kisah.

Tidak hanya itu, kepasifan perempuan juga sudah mulai ditampakkan pada tokoh Arini pada sekuen masa lalu yang membahas tentang pertemuan tokoh Arini dan tokoh Pras sebelum mereka menikah. Pengarang menyisipkan sebuah teks intertekstual dengan menganalogikan tokoh Arini dengan tokoh dalam teks intertekstual tersebut. Teks tersebut adalah kisah tentang putri dan pangeran berkuda putih yang disisipkan sebagai imajinasi tokoh Arini. Pada titik ini, pengarang menganalogikan tokoh Arini dengan tokoh putri di dalam dongeng 
sehingga posisi keduanya menjadi kongruen.

Kisah-kisah dongeng tersebut telah banyak dikaji dalam perspektif gender dan menunjukkan kesimpulan yang sama yaitu atribut aktif yang melekat pada tokoh pangeran dan atribut pasif yang melekat pada tokoh putri. Hal tersebut khususnya tampak pada akhir cerita dimana tokoh pangeran datang dan kedatangan tokoh tersebut adalah pembebasan tokoh putri dari penderitaan. Sebagai contoh, kisah Cinderella, Snow White, dan Sleeping Beauty memiliki jalan narasi yang kurang lebih sama, dengan menampilkan tokoh utama perempuan yang menderita dan di akhir cerita pangeran datang membawa tokoh tersebut menuju kebahagiaan. Dengan begitu, pengarang hendak menunjukkan secara tidak langsung kepasifan tokoh perempuan dan keaktifan tokoh laki-laki.

Hal yang sama terjadi pada tokoh Mei Rose yang juga menunjukkan indikasi pasif walaupun tokoh tersebut didapuk menjadi tokoh utama solo dalam babak yang ia wakili sebelum pertemuannya dengan tokoh Pras. Penggunaan sudut pandang pertama dengan kata 'aku' untuk merujuk tokoh tersebut menjadi penegas bahwa tokoh Mei Rose dilekati karakter aktif yang melebihi tokoh Arini. Namun, hal tersebut secara otomatis mendekonstruksi makna narasi ketika sekuen bergerak menuju tokoh Mei Rose dan tokoh Pras bertemu.

Karakter aktif tokoh Mei Rose tergantikan oleh pasif dan mulai menunjukkan ketergantungan pada tokoh laki-laki untuk melanjutkan narasi hidupnya. Tidak hanya itu, perjalanan spiritualitas yang dialami tokoh Mei Rose datang hampir bersamaan dengan karakter pasif yang tiba-tiba dilekatkan kepada tokoh tersebut. Perjalanan spiritualitas keislaman yang dialami tokoh Mei Rose seketika menunjukkan betapa lemahnya tokoh tersebut sehingga membutuhkan tokoh laki-laki untuk membimbingnya. Terbukti, ketika tokoh Mei Rose meminta tokoh Pras untuk membimbingnya dalam mempelajari islam. Secara tidak langsung, hal tersebut berarti Nadia sebagai mengarang mengakui bahwa Islam mengandung nilai-nilai patriarki.

\section{Signifikansi Posisi Hierarkis Perempuan Dalam Karya Asma Nadia}

Di tengah pergulatannya dengan Sastra Wangi, Forum Lingkar Pena hadir dengan konsep perempuan yang benar-benar berbeda dengan gambaran vulgar perempuan dalam Sastra Wangi dengan segala kebebasan seksual yang mengatasnamakan hak penuh perempuan terhadap tubuhnya. Forum Lingkar Pena 
memandang perempuan yang ditampilkan oleh Sastra Wangi sebagai degradasi moral yang justru menandakan perempuan masih jauh dari standar liberasi dan persamaan yang menjadi spirit dalam Islam (Azwar, 2012). Dengan melihat konteks sosial dan ideologis yang ada, dapat diasumsikan bahwa Forum Lingkar Pena hendak menawarkan sebuah perspektif baru dalam memaknai kebebasan dan kesetaraan perempuan, yaitu kebebasan dan kesetaraan yang sesuai nilai-nilai yang digaungkan dalam Islam. Dengan begitu, perempuanperempuan yang ditampilkan di dalam karya-karya Forum Lingkar Pena, khususnya karya Asma Nadia, ditampilkan sesuai hukum-hukum syari'ah untuk menandai kebebasan dan kesetaraannya.

Namun, yang perlu diperhatikan adalah representasi perempuan yang ditampilkan dalam novel-novelnya menunjukkan hal yang sebaliknya. Melalui analisa tekstual di atas, diketahui bahwa perempuan masih direpresentasikan memiliki posisi hierarkis yang lebih rendah dibandingkan pria. Eksistensi novel-novel Asma Nadia dengan representasi perempuan demikian masih melegitimasi nilai patriarki dimana perempuan dipandang sebagai makhluk nomor dua, lemah dan merupakan hak milik laki-laki. Hal-hal tersebut merupakan ciri dan karakteristik umum ideologi patriarki yang umum ditemui.

Hal ini menunjukkan ada dua sisi yang saling berkontradiksi dalam bangunan Forum Lingkar Pena yang terletak pada bangunan makro yang beroperasi pada tingkat sosial dan bangunan mikro yaitu refleksi dalam narasi yang dibangun. Dapat dilihat, penggambaran perempuan modern dengan karir dan mandiri di dalam narasi adalah sebuah fakta, seperti yang ditampilkan pada tokoh Asmara dalam Assalamualaikum Beijing dan tokoh Mei Rose dalam Surga Yang Tak Dirindukan. Akan tetapi, pandangan itu diruntuhkan oleh unit-unit linguistik dan elemenelemen narasi yang beroperasi secara internal di dalam teks. Dengan begitu, apa yang disampaikan adalah semandiri dan modern apapun perempuan, pada hakikatnya ia adalah hak milik laki-laki.

Jika dirujuk pada teks-teks suci dalam Islam, dogma bahwa Hawa diciptakan dari tulang rusuk Adam adalah dogma yang memberikan justifikasi pada kepemilikan perempuan oleh laki-laki (Manshur, 2012). Akan tetapi, tafsir kontemporer atas teks yang sama dengan memasukkan perspektif perempuan menunjukkan hal yang sama sekali berbeda. Penggunaan istilah 'tulang 
rusuk' tidak berarti perempuan tercipta secara literal dari tulang rusuk laki-laki, akan tetapi hal tersebut bersifat majazi atau makna kiasan. Hal itu merujuk pada sifat perempuan dan bukan berarti perempuan adalah separuh laki-laki seperti apa yang diyakini di dalam tafsirtafsir klasik (Ch, 20101). Hal serupa juga ditulis oleh beberapa pemikir islam kontemporer seperti Amina Wadud (Wadud, 1999), Riffat Hasan (Bidayah, 2013), dan khususnya dalam konteks Indonesia, KH. Muhammad Husein (Muhammad, 2004). Pemikiran tersebut menandai dialektika dalam khasanah keilmuan Islam dan implikasi sosialnya dengan memasukkan perspektif perempuan, sesuatu yang belum pernah terjadi sebelumnya.

\section{Simpulan}

Dengan pemaparan di atas, dapat disimpulkan bahwa Asma Nadia yang merupakan figur prominent dalam Forum Lingkar Pena, masih menampilkan posisi hierarkis antara laki-laki dan perempuan di dalam karya-karyanya. Hal tersebut berarti bahwa makna nilai liberation dan equality yang dipegang oleh Asma Nadia masih berlandaskan tafsir klasik atas teksteks suci agama Islam. Dengan begitu, nilai persamaan yang dimaksudkan menjadi semangat Forum Lingkar Pena, tidak tercermin dalam ranah mikro di dalam Narasi yang dibangun Asma Nadia.

\section{Daftar Pustaka}

Arnez, M. (2009). Dakwah By The Pen: Reading Helvy Tiana Rosa's Bukavu. Indonesia and The Malay World Journal, 45-65.

Arnez, M. (2010). Empowering Women Through islam: Fatayat NU Between Tradition And Change. Journal Of Islamic Studies, 59-88.

Arnez, M. (2016). Dimensions of Morality: The Transnational Writers' Collective Forum Lingkar Pena. Bijdragen tot de Taal, 449478.

Arnez, M., \& Dewojati, C. (2010). Sexuality, Morality and The Female Role : Observation On Recent Indonesian's Women's

Literature. Ein Dienst der ETHBibliothek.

Azwar. (2012). Fiksimorfosis Forum Lingkar Pena: Dari Ideologi Ke Industri. Magister Ilmu Komunikasi Universitas Indonesia. Bhasin, K. (1996). Menggugat Patriarki:

Pengantar Tentang Persoalan

Dominasi Terhadap Perempuan. Jogjakarta: Yayasan Bentang Budaya. 
Bidayah, A. (2013). Riffat Hasan Dan

Wacana Baru Penafsiran. Kalimah

Volume 11, 305-321.

Ch, M. (20101). Gender Di Pesantren

Salaf: Why Not? Malang: UIN-

MALIKI Press.

El Saadawi, N. (2001). Perempuan Dalam

Budaya Patriarki. Jogjakarta:

Pustaka Pelajar.

Hall, S. (1997). Representation: Cultural

Representations and Signifying

Practices. London: SAGE.

Manshur, A. Q. (2012). Fikih Wanita:

Segala Hal Tentang Wanita Dalam

Islam. Jakarta: Zaman.

Muhammad, H. (2004). Islam Agama

Ramah Perempuan: Pembelaan

Kiai Pesantren. Jogjakarta: LKiS.

Tong, R. P. (2010). Feminist Thought:

Pengantar Paling Komprehensif

Kepada Aliran Utama Pemikiran

Feminis. Jogjakarta: Jalasutra.

Wadud, A. (1999). Qur'an And Woman:

Rereading The Sacred Text From A

Woman's Perspective. Oxford:

Oxford University Press. 